\title{
Mapping Protein Interfaces by a Trifunctional Cross-Linker Combined with MALDI-TOF and ESI-FTICR Mass Spectrometry
}

\author{
Andrea Sinz, Stefan Kalkhof, and Christian Ihling \\ Biotechnological-Biomedical Center, Faculty of Chemistry and Mineralogy, University of Leipzig, Leipzig, \\ Germany
}

Chemical cross-linking of protein complexes has gained renewed interest in combination with mass spectrometric analysis of the reaction products as it allows a rapid mapping of protein interfaces, which is crucial for understanding protein/protein interactions. The identification of cross-linking products from the complex mixtures created after the cross-linking reaction, however, remains a daunting task. To facilitate the identification of cross-linking products, we explore the use of the commercially available biotinylated cross-linking reagent sulfo-SBED (sulfosuccinimidyl-2-[6-(biotinamido)-2-(p-azidobenzamido)-hexanoamido]ethyl-1,3'-dithiopropionate). This trifunctional cross-linker possesses one amine-reactive and one photoreactive site and, additionally, allows an affinity-based enrichment of cross-linker containing species. As a model system, we chose the $\mathrm{Ca}^{2+}$-dependent complex between calmodulin and its target peptide M13, which represents a part of the C-terminal sequence of the skeletal muscle myosin light chain kinase. After the cross-linking reaction, matrix-assisted laser desorption/ionization time-of-flight mass spectrometry (MALDI-TOFMS) and one-dimensional gel electrophoresis were employed to check for the extent of cross-linking product formation. The cross-linking reaction mixtures were subjected to tryptic in-solution digestion. Biotinylated peptides, e.g., peptides that had been modified by the cross-linker as well as cross-linked peptides, were enriched on monomeric avidin beads after several washing steps had been performed. Peptide mixtures were analyzed by MALDI-TOFMS, nano-high-performance liquid chromatography (HPLC)/nano-electrospray ionization Fourier transform ion cyclotron resonance mass spectrometry (ESI-FTICRMS), and tandem MS. We demonstrate that an enrichment of cross-linker containing species allows a more efficient identification of interacting amino acid sequences in protein complexes. This strategy is expected to be especially beneficial for investigating large protein assemblies. (J Am Soc Mass Spectrom 2005, 16, 1921-1931) @ 2005 American Society for Mass Spectrometry

$\mathrm{A}$ detailed knowledge of interacting amino acid sequences in protein complexes is of outstanding importance for understanding protein functions in a cell. A number of well-established analytical techniques are available to address the questions of spatial and topological organizations of protein complexes, currently primarily X-ray crystallography and NMR spectroscopy. Both techniques yield detailed information on the protein structure, however, NMR spectroscopy requires rather large quantities of pure protein in a specific solvent, and for X-ray studies the protein has to be crystallized. A large-scale analysis of proteins in the post-genomic research requires sensitive techniques for high-throughput analysis such as mass spectrometry. Among the mass spectrometric techniques used for structural studies of proteins are hydro-

Published online October 24, 2005

Address reprint requests to Dr. A. Sinz, Biotechnological-Biomedical Center, Faculty of Chemistry and Mineralogy, University of Leipzig, Linnestrasse 3, D-04103 Leipzig, Germany. E-mail: sinz@chemie.uni-leipzig.de gen/deuterium exchange [1], analysis of the intact noncovalent complexes in the gas-phase [2], and chemical cross-linking followed by enzymatic digestion and mass spectrometric identification of the cross-linked peptides $[3,4]$. Mass spectrometry $[5,6]$ is the method of choice for the latter studies because of its high sensitivity, enabling rapid analysis of the complex mixtures obtained from enzymatic digests of cross-linking reaction mixtures $[7,8]$. Chemical cross-linking combined with mass spectrometry represents a low-resolution alternative to NMR spectroscopy and X-ray crystallographybased methods. However, despite the apparent straightforwardness of the cross-linking approach, cross-linking has always been a trial and error process for a particular protein complex, and identification of cross-linking products is far too often hampered by the complexity of the cross-linking reaction mixture. To overcome these difficulties, a number of strategies have been employed to facilitate detection of the cross-linking products, such as using isotope-labeled cross-linkers or proteins, fluorogenic cross-linkers, or cross-linkers creating charac- 
teristic fragment ions during mass spectrometric detection [4]. A relatively new group of reagents are trifunctional cross-linkers, such as the cross-linker sulfo-SBED which was used for the present study, possessing three different reactive groups. The trifunctional approach incorporates elements of the heterobifunctional cross-linker concept with the additional third functional group being able to specifically link to a third protein or being used for affinity purification of the cross-linking products in case a biotin moiety is incorporated [9].

In the present study, we explore the possibility that a combination of chemical cross-linking using the affinity cross-linker sulfo-SBED and FTICR (Fourier transform ion cyclotron resonance) mass spectrometry allows an efficient identification of interacting amino acid sequences in protein complexes, as cross-linker containing species are enriched by an affinity purification step after the cross-linking reaction. We apply this strategy to the complex between the $17 \mathrm{kDa}$-protein calmodulin $(\mathrm{CaM})$ and its target peptide M13 from the skeletal muscle myosin light chain kinase, which has already been studied by our group using chemical cross-linking and FTICR mass spectrometry [10].

CaM is a small (148 amino acids), acidic protein belonging to the class of EF-hand proteins, which is found ubiquitously in animals, plants, fungi, and protozoa [11]. CaM serves as a calcium-dependent regulator in many metabolic pathways [12]. Upon calcium binding, CaM adopts a dumbbell structure [13] consisting of two lobes connected by a flexible central helix [14]. CaM is known to bind with high affinity to various target proteins and peptides, with dissociation constants ranging between $10^{-7}$ and $10^{-11} \mathrm{M}$ [11].

The myosin light chain kinase of the skeletal muscle (skMLCK) belongs to a class of CaM-dependent enzymes consisting of ca. 600 amino acids depending on the species. Binding studies using chymotryptic fragments of the rabbit skMLCK and synthetic peptides identified a C-terminal peptide of the skMLCK as the CaM-binding region [15]. This 26-amino acid peptide has been designated as M13, comprising amino acids 577-602 of the rabbit skMLCK (or amino acids 565-590 of the human skMLCK, respectively). Accordingly, M13 represents the complete CaM-interacting sequence of skMLCK and, thus, can be employed as a substitute for the total kinase to analyze the structures of $\mathrm{CaM}$ and the interacting skMLCK-sequence within the complex [16]. The three-dimensional structure of the CaM/M13 complex was solved several years ago by multi-dimensional NMR spectroscopy [16] and, moreover, we had also studied this complex by chemical cross-linking and FTICR mass spectrometry [10] making this complex an ideal system to test our method.

Recently, Hurst et al. demonstrated the application of the cross-linker sulfo-SBED in combination with MALDI-TOF mass spectrometry for identification of intramolecular cross-linking products and cross-linker modified amino acids within the 13-amino acid model peptide neurotensin [17]. Sulfo-SBED had also been employed to identify an interacting region between $\alpha$-crystallin and alcohol dehydrogenase [18]. ${ }^{\circ} \mathrm{To}{ }^{\circ}$ our knowledge, the present study is the first report on an affinity purification of cross-linker-containing, biotinylated species in combination with MALDI-TOFMS and ESI-FTICRMS. The reported strategy presents a straightforward approach with the perspective to obtain structural data of protein complexes within a few days.

\section{Experimental}

\section{Material}

Bovine brain CaM was obtained from Calbiochem (Schwalbach am Taunus, Germany) and used without further purification. The skMLCK peptide (M13) was a generous gift from Dr. Ad Bax, National Institutes of Health, U.S.A. The purities of CaM and M13 were checked by MALDI-TOF mass spectrometry and onedimensional gel electrophoresis (SDS-PAGE). The cross-linking reagent sulfo-SBED (sulfosuccinimidyl-2-[6(biotin-amido)-2-(p-azidobenzamido)-hexanoamido]ethyl-1,3'-dithiopropionate) and UltraLink immobilized monomeric avidin were purchased from Pierce (Rockford, IL). Trypsin (sequencing grade) was obtained from Roche Diagnostics (Mannheim, Germany). LHRH (luteinizing hormone releasing hormone), 2,5dihydroxy benzoic acid, $\alpha$-cyano-4-hydroxycinnamic acid, as well as proteins and peptides for MALDITOFMS calibration were purchased from Sigma (Taufkirchen, Germany). Buffer reagents were obtained from Sigma (Taufkirchen, Germany) at the highest available purity. Nano-HPLC solvents were spectroscopic grade (Uvasol, VWR, Darmstadt, Germany). Water was purified with a Direct-Q5 water purification system (Millipore, Eschborn, Germany).

\section{Cross-Linking Reactions}

For cross-linking experiments, an aqueous CaM stock solution $(1 \mathrm{mg} / \mathrm{ml})$ was diluted with $20 \mathrm{mM}$ HEPES buffer ( $\mathrm{pH}$ 7.0) containing $1 \mathrm{mM} \mathrm{CaCl}$ to give three solutions with volumes of $1400 \mu \mathrm{l}$ each, containing $\mathrm{CaM}$ at a concentration of $10 \mu \mathrm{M}$.

To each CaM solution, a $100 \mathrm{mM}$ solution of sulfoSBED in DMSO was added, yielding molar excesses of cross-linker over protein/peptide of 20,50, and 100, respectively. The mixtures were incubated for $60 \mathrm{~min}$ at room temperature. Excess of nonreacted cross-linker was removed using Microcon-YM-10 filters (Millipore, Eschborn, Germany) and the three samples (20-, 50-, and 100-fold excess of sulfo-SBED) were recovered in 3 $\times 1400 \mu \mathrm{l}$ of $20 \mathrm{mM}$ HEPES buffer ( $\mathrm{pH}$ 7.0) containing $1 \mathrm{mM} \mathrm{CaCl} 2$. One $200-\mu l$ aliquot was taken from each sample and stored at $-20{ }^{\circ} \mathrm{C}$ before SDS-PAGE and MALDI-TOFMS.

A $330 \mu \mathrm{M}$ aqueous solution of M13 was added to the three reaction mixtures to give a final M13 concentra- 
tion of $10 \mu \mathrm{M}$. The samples were irradiated with long wavelength UV light (365 nm) using a MinUvis lamp (8 watt, Desaga, Heidelberg, Germany). During irradiation, the reaction mixtures were kept at $0{ }^{\circ} \mathrm{C}$ in an ice bath. Two hundred- $\mu$ l aliquots were taken after $15 \mathrm{~min}$, $30 \mathrm{~min}, 60 \mathrm{~min}, 120 \mathrm{~min}, 8 \mathrm{~h}$, and $16 \mathrm{~h}$. The reactions were terminated by freezing the samples at $-20^{\circ} \mathrm{C}$. Before SDS-PAGE and MALDI-TOFMS, the solutions were desalted using Microcon-YM-10 filters (Millipore, Eschborn, Germany). As, in contrast to previously conducted ${ }^{\circ}$ experiments ${ }^{\circ}$ with $^{\circ}$ sulfo-SBED ${ }^{\circ}[17],{ }^{\circ}$ we $^{\circ}$ did $^{\circ}$ not aim to cleave the disulfide bond of the cross-linker, there was a need to maintain nonreducing conditions during all stages of the analysis.

\section{SDS-PAGE and Enzymatic Proteolysis}

$\operatorname{SDS} \operatorname{PAGE}^{\circ}\left(15 \%,{ }^{\circ}\right.$ Coomassie $^{\circ}$ staining,,$[19]^{\circ}$ under $^{\circ}$ nonreducing conditions was employed to check for the extent of cross-linking product formation in the reaction mixtures. To $100 \mu \mathrm{l}$ of each aliquot, $8 \mathrm{M}$ urea was added and in-solution digestion was performed by adding 0.25 $\mu \mathrm{g}$ trypsin (corresponding to an enzyme/substrate ratio of $\sim 1: 80$ ) followed by incubation at $37{ }^{\circ} \mathrm{C}$ for $16 \mathrm{~h}$ before the samples were subjected to affinity purification on avidin beads.

\section{Affinity Purification of Cross-Linker Containing Species}

Avidin affinity capture of biotinylated species was performed using immobilized monomeric avidin (Pierce Inc., Rockford, IL). The avidin beads in $50 \%$ aqueous suspension were prepared for affinity purification of biotinylated species in the following way: the beads were successively washed with $50 \mathrm{mM}$ sodium phosphate buffer (pH 7.0), $100 \mathrm{mM}$ glycine buffer ( $\mathrm{pH} 2.8), 50 \mathrm{mM}$ sodium phosphate buffer ( $\mathrm{pH} 7.0), 2 \mathrm{mM}$ biotin in 100 mM HEPES buffer ( $\mathrm{pH} 7.5), 100 \mathrm{mM}$ glycine buffer, $(\mathrm{pH}$ 2.8) $15 \%$ methanol in $50 \mathrm{mM} \mathrm{NH} \mathrm{HCO}_{3}$, and $50 \mathrm{mM}$ sodium phosphate buffer ( $\mathrm{pH} 7.0)$. As a last step, the same volume of water was added to the beads and $50 \mu \mathrm{l}$ of peptide digest was added to $140 \mu$ l of the avidin beads suspension. The mixtures were incubated at room temperature in the dark for $3 \mathrm{~h}$, centrifuged, and the supernatants were collected. The avidin beads were washed three times with $400 \mu \mathrm{l}$ of $50 \mathrm{mM}$ sodium phosphate buffer (pH 7.0) and twice with 15\% methanol in $50 \mathrm{mM} \mathrm{NH}_{4} \mathrm{HCO}_{3}$. Biotinylated peptides, thus crosslinker containing species, were eluted from the beads with a $50 \%$ aqueous acetonitrile solution containing $0.4 \%$ formic acid. The fractions (one supernatant, three phosphate fractions, two methanol fractions, and two acetonitrile fractions from each sample) were brought to complete dryness in a vacuum concentrator (Eppendorf, Hamburg, Germany). The supernatants and the phosphate fractions were desalted using C18 ZipTips (Millipore, Eschborn, Germany). All samples were col- lected in $30 \mu \mathrm{l}$ of $0.1 \%$ formic acid before mass spectrometric analysis by MALDI-TOFMS and nano-HPLC/ nano-ESI-FTICRMS was performed.

\section{MALDI-TOF Mass Spectrometry}

MALDI-TOFMS was performed on a Voyager DE RP Biospectrometry Workstation (Applied Biosystems, Foster City, CA) equipped with a nitrogen laser (337 $\mathrm{nm})$. The instrument was run in positive ionization mode and measurements were performed in the linear mode $(m / z 15,000$ to 40,000$)$ as well as in the reflector mode ( $\mathrm{m} / \mathrm{z} 1000$ to 6000$)$ using 2,5-dihydroxy benzoic acid and $\alpha$-cyano-4-hydroxycinnamic acid (HCCA) as matrices. A saturated matrix solution was prepared in $30 \%$ (vol/vol) acetonitrile, $69.9 \%$ (vol/vol) water, and $0.1 \%$ (vol/vol) TFA. Samples were prepared using the dried droplet method by spotting $0.5 \mu$ l of matrix solution and $0.5 \mu \mathrm{l}$ of sample solution onto the target. Spectra from 800 laser shots were accumulated to one spectrum when operating the instrument in the reflector mode, and 1500 laser shots were added when spectra were acquired in the linear mode. In the linear mode, the instrument was calibrated using cytochrome $c\left([\mathrm{M}+\mathrm{H}]_{\text {average }}^{+}\right.$at $\left.m / z 12,361\right)$ and myoglobin ([M + $\mathrm{H}_{\text {average }}^{+}$at $m / z$ 16,952). For calibration in the reflector mode, signals of angiotensin I $\left([\mathrm{M}+\mathrm{H}]_{\text {mono }}^{+}\right.$at $m / z$ 1296.69), substance $\mathrm{P}\left([\mathrm{M}+\mathrm{H}]_{\text {mono }}^{+}\right.$at $\left.m / z 1347.74\right)$, and somatostatin (reduced form) $\left([\mathrm{M}+\mathrm{H}]_{\text {mono }}^{+}\right.$at $\mathrm{m} / \mathrm{z}$ 1637.72) were employed. Data acquisition and data processing were performed using the Voyager software version 5.1 and the Data Explorer software version 4.0 (Applied Biosystems, Foster City, CA).

\section{Nano-HPLC/Nano-ESI-FTICR Mass Spectrometry}

Enzymatic peptide mixtures from various stages of the avidin separation were separated by nano-HPLC. Nano-HPLC was carried out on an Ultimate Nano-LC system (Dionex, Idstein, Germany) equipped with a Switchos II column switching module and a Famos Micro Autosampler with a 20- $\mu$ l-sample loop. Samples were injected by the autosampler and concentrated on a trapping column (PepMap, C18, $300 \mu \mathrm{m} \times 5 \mathrm{~mm}, 3 \mu \mathrm{m}$, $100 \AA$, Dionex) with water containing $0.1 \%$ formic acid at flow rates of $20 \mu \mathrm{l} / \mathrm{min}$. After $3 \mathrm{~min}$ for desalting, the peptides were eluted onto the separation column (PepMap, C18, $75 \mu \mathrm{m} \times 150 \mathrm{~mm}, 3 \mu \mathrm{m}, 100 \AA$, Dionex), which had been equilibrated with 95\% A (Solvent A: water containing $0.1 \%$ formic acid). Peptides were separated using the following gradient: $0-30 \mathrm{~min}$ : 5-50\% B, 30-31 min: 50-95\% B, 31-45 min: 95\% B (Solvent B: acetonitrile containing $0.1 \%$ formic acid) at flow rates of $200 \mathrm{nl} / \mathrm{min}$ and detected based on their UV absorptions at 214 and $280 \mathrm{~nm}$. For LC/MS data acquisition, the Hystar software, version 2.3 (Bruker Daltonics, Billerica, MA) was used.

The nano-HPLC system was coupled on-line to an FTICR mass spectrometer equipped with a 7 tesla 
superconducting magnet (APEX II, Bruker Daltonics) and a nano-electrospray ionization source (Agilent Technologies, Waldbronn, Germany). For nano-ESIMS, distal coated fused-silica PicoTips (tip ID $8 \mu \mathrm{m}$, New Objective, Woburn, MA) were applied. The capillary voltage was set to $-1400 \mathrm{~V}$. Mass spectral data were acquired in the broadband mode over an $\mathrm{m} / \mathrm{z}$ range of 400 to 2000 with $256 \mathrm{k}$ data points, 10 scans were accumulated per spectrum, and 162 spectra were recorded for each LC/MS run. MS data acquisition was initialized from the Hystar software $10 \mathrm{~min}$ after initiation of the LC gradient. Data were acquired over 34.5 $\mathrm{min}$. Calibration of the instrument was performed with CID fragments (capillary exit voltage $250 \mathrm{~V}$ ) of the LHRH peptide ( 55 ( $m / z$ 499.2987), LHRH $\left([\mathrm{M}+\mathrm{H}]^{2+} \mathrm{m} / \mathrm{z}\right.$ 592.2358), y7 ( $m / z$ 749.3941), y8 ( $m / z$ 935.4734), LHRH $\left([\mathrm{M}+\mathrm{H}]^{+} \mathrm{m} / z\right.$ 1183.5643)). Data acquisition and data processing were performed using the XMASS software, version 7.0.3 (Bruker Daltonics). Before Fourier transformation the time-domain signals were doubly zero filled, followed by apodization with a sine function. 162 single spectra were projected into one final mass spectrum using the 'Projection' tool in the XMASS software $[20]^{\circ}$ After $^{\circ}$ deconvolution ${ }^{\circ}$ of ${ }^{\circ}$ the ${ }^{\circ}$ ESI $^{\circ}$ mass $^{\circ}$ spectra, monoisotopic peptide masses $\left([\mathrm{M}+\mathrm{H}]^{+}\right)$were manually labeled and the created peak lists were used for calculating masses of cross-linking products by the GPMAW software.

\section{Nano-ESI-MS/MS Analysis}

MS/MS data of a fraction eluted from the avidin beads with $50 \%$ aqueous acetonitrile and $0.4 \%$ formic acid were acquired using a linear ion trap mass spectrometer (Finnigan LTQ, Thermo Electron Corp., Waltham, MA, USA) equipped with a nanospray source (PicoView 550, New Objective). The sample was loaded onto a combined reversed-phase column / spray emitter (PicoFrit, BioBasic C-8, $75 \mu \mathrm{m} \times 10 \mathrm{~cm}$, tip-ID: $15 \mu \mathrm{m}$, New Objective) using a 1- $\mu$ l-sample loop. Peptides were eluted with the following gradient: $90 \%$ A for $10 \mathrm{~min}$, $90 \%$ A to $80 \%$ B in $15 \mathrm{~min}, 80$ to $95 \%$ B in $10 \mathrm{~min}, 95 \%$ B for $10 \mathrm{~min}$ (solvent $\mathrm{A}: \mathrm{H}_{2} \mathrm{O}+0.1 \%$ formic acid, solvent $\mathrm{B}$ : acetonitrile $+0.1 \%$ formic acid) at a flow rate of $300 \mu \mathrm{l} / \mathrm{min}$. Gradient and solvent flow rate were generated using the Surveyor MS pump (Thermo Electron Corp., Waltham, MA, USA) with a 1:1000 flow split. Eluted peptides were sprayed directly from the PicoFrit column into the mass spectrometer by applying a spray voltage of $1.4 \mathrm{kV}$.

MS-data were acquired over $45 \mathrm{~min}$, each full MS scan ( $m / z$ z 500-2000) was followed by one zoom scan of the most intense signal in the full MS spectrum to define its charge state and one MS/MS scan (isolation window $2 \mathrm{u}$ ) of the same species. Dynamic exclusion was enabled to allow detection of less abundant ions. The LTQ mass spectrometer and the Surveyor MS pump were controlled by the Xcalibur software version 1.4 (Thermo Electron Corp., Waltham, MA). (a)

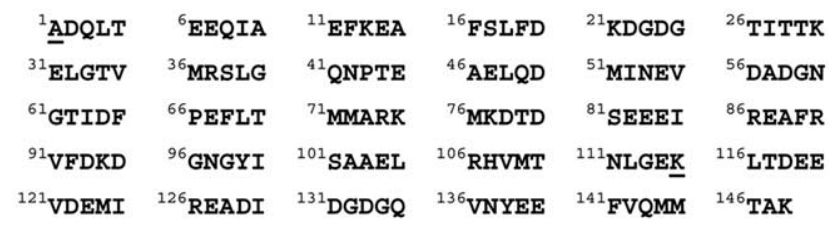

(b)

${ }^{1}$ KRRWK ${ }^{6}$ KNFIA ${ }^{11}$ VSAAN ${ }^{16}$ RFKKI ${ }^{21}$ SSSGA ${ }^{26} \mathrm{~L}$

Figure 1. Amino acid sequences of (a) CaM and (b) M13. CaM was found to be N-acetylated (Ac-Ala) and to contain a trimethylated lysine in position 115. The modified amino acids Ala- 1 and Lys-115 are underlined.

\section{Identification of Reaction Products}

Cross-linking products and modified peptides were identified using the General Protein Mass Analysis for Windows (GPMAW) software, version 6.20 (Lighthouse Data, ${ }^{\circ}$ Odense, ${ }^{\circ}$ Denmark $)^{\circ}\left(\right.$ available ${ }^{\circ}$ at: ${ }^{\circ}$ http: // welcome. to/gpmaw). ${ }^{\circ}$ Proteolytic ${ }^{\circ}$ cleavages $^{\circ}$ at $^{\circ}$ modified $^{\circ}$ amino acids, such as the trimethylated K115 in CaM as well as amino acids modified by cross-linking reagents, were excluded. The $\mathrm{N}$-terminus of $\mathrm{CaM}$ was excluded from possible cross-linking since it is acetylated.

\section{Determination of Distances Between Atoms in the CaM/M13 Complex}

The NMR structure of the CaM/M13 complex is deposited ${ }^{\circ}{ }^{\circ}$ the ${ }^{\circ} \mathrm{RCSB}^{\circ}$ Protein ${ }^{\circ} \mathrm{Data}^{\circ} \mathrm{Bank}^{\circ}$ (http:/ / www.rcsb. org $/ \mathrm{pdb} /)^{\circ}$ under $^{\circ}$ the ${ }^{\circ}$ entry $^{\circ} 2 \mathrm{BBM}^{\circ}[16]^{\circ}$ Based $^{\circ}$ on $^{\circ}$ the atom coordinates of this structure, the distances between atoms of reactive groups were determined using the ${ }^{\circ} \mathrm{VMD}-\mathrm{XPLOR}{ }^{\circ}$ visualization ${ }^{\circ}$ package ${ }^{\circ}[21]^{\circ}$ (available at: ${ }^{\circ}$ ttp://vmd-xplor.cit.nih.gov).

\section{Results and Discussion}

\section{Characterization of CaM and M13}

The basis for conducting cross-linking experiments with CaM and M13 consists in a detailed description of

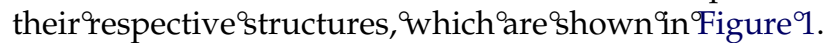
The characterization of both CaM and M13 has been described ${ }^{\circ}$ elsewhere ${ }^{\circ}[10]$.

\section{Cross-Linking Reaction}

Scheme 1 shows the structure of the trifunctional crosslinker sulfo-SBED possessing one photo-reactive and one amine-reactive site in addition to a biotin moiety, thus allowing for an affinity purification of cross-linker containing species. Possible reaction products between sulfo-SBED and the protein/peptide, which were considered ${ }^{\circ}{ }^{\circ}$ this ${ }^{\circ}$ study, ${ }^{\circ}$ are ${ }^{\circ}$ presented ${ }^{\circ}$ in Table ${ }^{\circ}$. . Reaction 


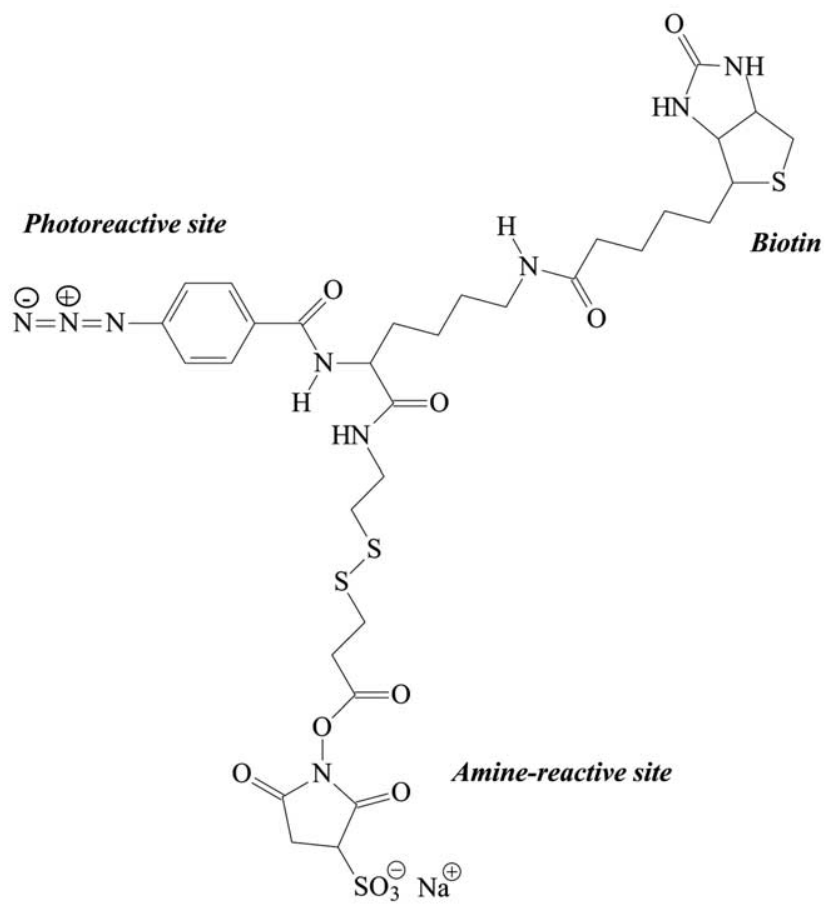

Scheme 1. Structure of the trifunctional cross-linker sulfoSBED.

products include cross-linked species in which both the N-hydroxy succinimide (NHS) group and the azide group of sulfo-SBED have reacted with the protein/ peptide, resulting in the formation of intramolecular (between parts of one protein) and/or intermolecular (between the different complex constituting components) ${ }^{\circ}$ cross-linking ${ }^{\circ}$ products ${ }^{\circ}[4] .{ }^{\circ}$ Moreover, ${ }^{\circ}$ modifications of the protein/peptide are created either by reaction of the photoreactive aryl azide group or by reaction of the NHS-ester with lysine groups or the free $\mathrm{N}$ terminus ${ }^{\circ}\left(\right.$ Table $\left.^{\circ} 1\right)$. In ${ }^{\circ}$ the ${ }^{\circ}$ latter ${ }^{\circ}$ case, $^{\circ}$ the ${ }^{\circ}$ azide ${ }^{\circ}$ group ${ }^{\circ}$ is converted to an amine group or, alternatively, stays intact. Oxidized analogs of sulfur-containing species are also occurring quite frequently, which had already been perceived ${ }^{\circ}$ by $^{\circ}$ the $^{\circ}$ studies $^{\circ}$ of $^{\circ} \mathrm{Hurst}^{\circ} \mathrm{et}^{\circ}{ }^{\circ} .^{\circ}$ [17]..$^{\circ}$ Therefore, we chose a low-intensity UV lamp for conducting the photoreaction to reduce unwanted oxidation reactions in the protein as much as possible. Moreover, we did not cleave the cross-linker with a reducing agent, such as dithiothreitol (DTT) as we employed FTICR mass spectrometry ${ }^{\circ}[22],{ }^{\circ}$ which ${ }^{\circ}$ allows ${ }^{\circ}$ acquisition ${ }^{\circ}$ of $^{\circ} \mathrm{MS}^{\circ}$ data with unprecedented mass accuracy, thus yielding an additional constraint for correct assignment of crosslinker containing species.

The cross-linking reaction conditions in respect to protein/peptide concentration, buffer system, buffer concentration, and $\mathrm{pH}$ value had already been optimized in our previous cross-linking experiments with the ${ }^{\circ} \mathrm{CaM} / \mathrm{M}_{13}{ }^{\circ}$ system $^{\circ}[10]^{\circ}$ and $^{\circ}$ were $^{\circ}$ employed ${ }^{\circ}$ for ${ }^{\circ}$ the present experiments with sulfo-SBED. The only difference to our previously conducted cross-linking studies is that cross-linking experiments were carried out in a
Table 1. Sulfo-SBED reaction products with their respective mass increases $(\Delta \mathrm{m})$. For the photoreactive site of sulfo-SBED, a possible reaction product is depicted for a protein amine group, but reaction also occurs with $\mathrm{CH}$-groups
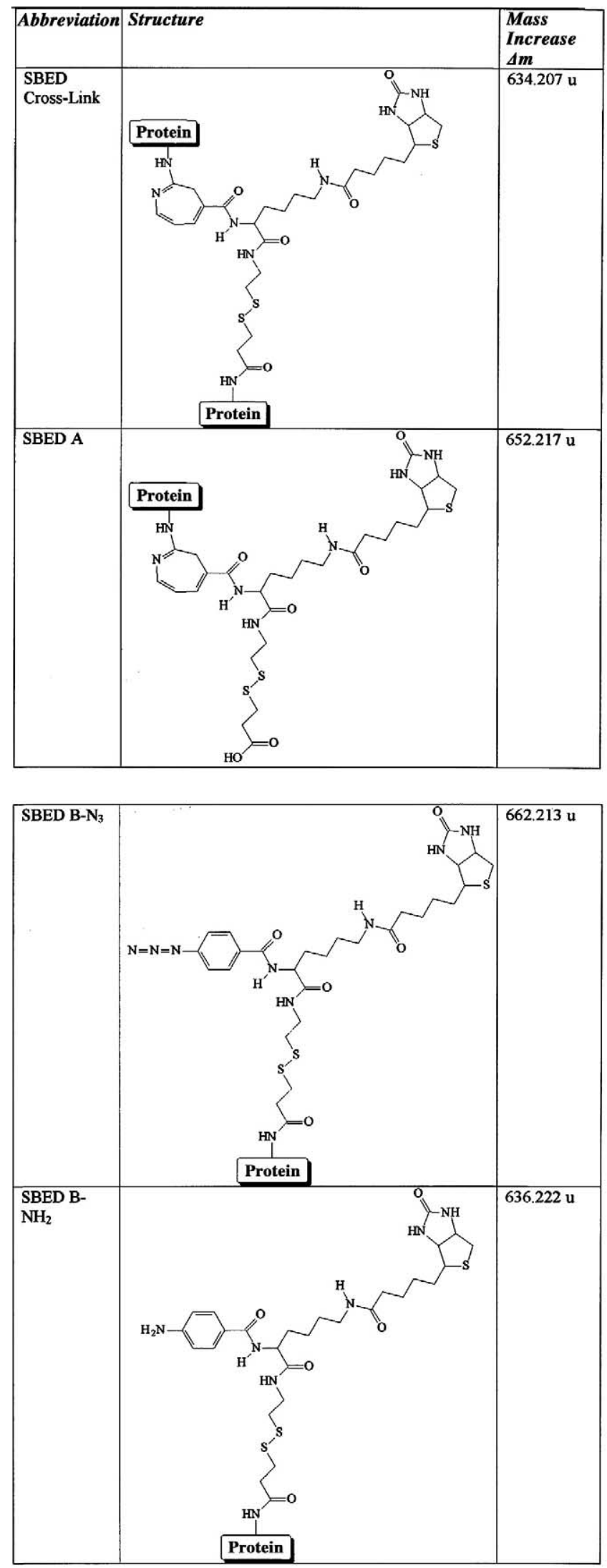
(a)

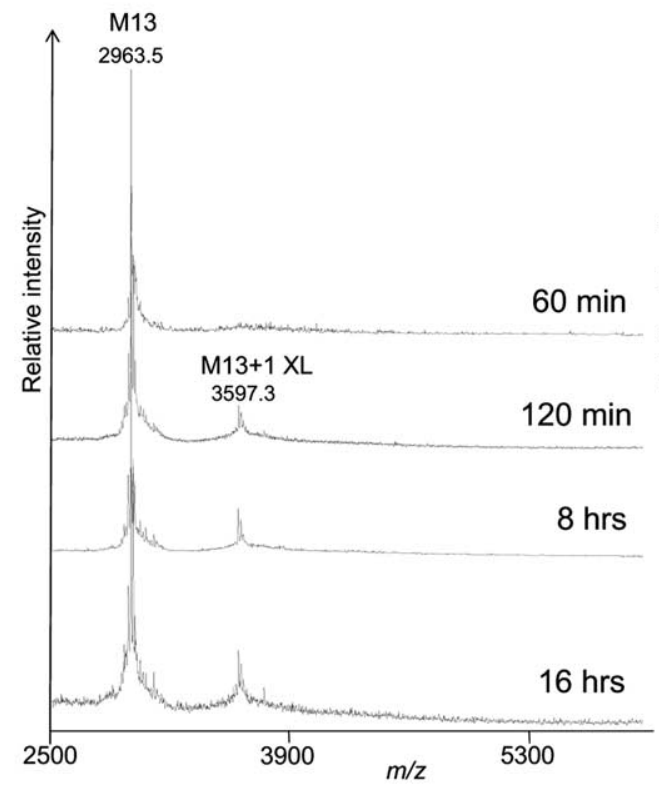

(b)

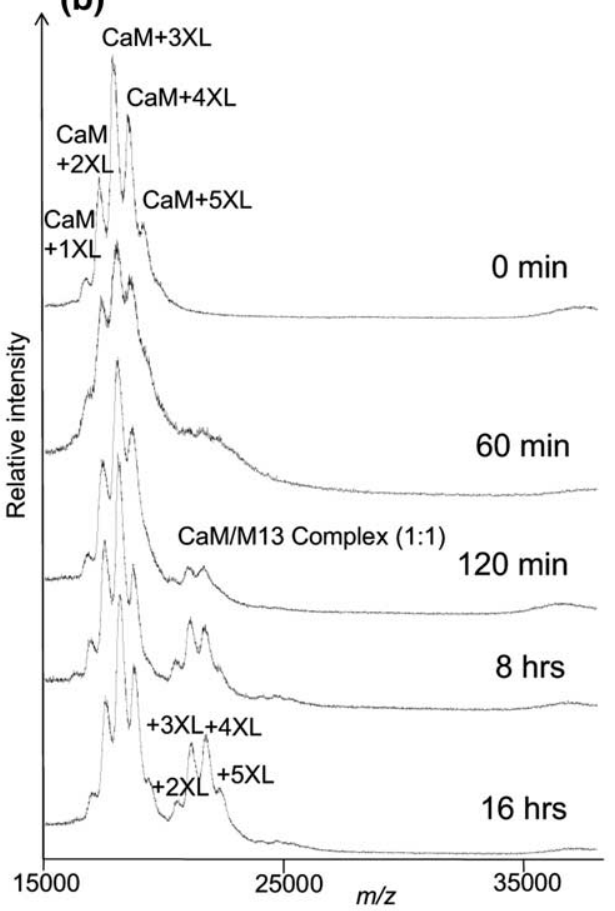

Figure 2. MALDI-TOF mass spectra of reaction mixture between CaM and M13 with 100-fold excess of sulfo-SBED at increasing UV irradiation times (0 min to $16 \mathrm{~h}$ ). Please note that the sample at 0 min irradiation time was prepared before adding M13 to the reaction mixture. (a) MALDI-TOF mass spectra (reflector mode, $m / z$ 2500-6000) showing increased modification of M13 by sulfo-SBED with longer UV irradiation times; (b) MALDI-TOF mass spectra (linear mode, $m / z$ 15,000-40,000) showing increased modification of CaM by sulfo-SBED as well as increased formation of a CaM/M13 (1:1) complex with longer UV irradiation times. XL: cross-linker.

two-stage fashion, in which calcium-loaded CaM was reacted with sulfo-SBED first. After $60 \mathrm{~min}$, excess of sulfo-SBED was removed, M13 was added, and the reaction mixtures were irradiated with long-wavelength UV $(365 \mathrm{~nm})$ for varying times between $10 \mathrm{~min}$ and $16 \mathrm{~h}$. As cross-linking conducted with a 100-fold excess of sulfoSBED over the protein/peptide concentration gave the highest yield of cross-linking products (according to SDS-PAGE), we used this fixed concentration of sulfoSBED (100-fold excess) for further analyses of crosslinking products.

Figure $2{ }^{\circ}$ shows ${ }^{\circ}$ MALDI-TOF ${ }^{\circ}$ mass $^{\circ}$ spectra ${ }^{\circ}$ of the ${ }^{\circ}$ crosslinking reaction mixtures recorded in the reflector(Figure $^{\circ} 2 a^{\circ}{ }^{\circ}$ and $^{\circ}$ in $^{\circ}$ the $^{\circ}$ linear ${ }^{\circ}$ mode $^{\circ}\left(\right.$ Figure $\left.^{\circ} 2 b\right){ }^{\circ}$ which allowed for estimating the extent of CaM and M13 modification as well as of cross-linking product formation between both binding partners. Additionally, we conducted SDS-PAGE for reaction control (data not shown). When conducting cross-linking experiments, one has to take care that only a few cross-linker molecules are introduced into the molecule as, otherwise, there might be a distortion of the three-dimensional structures of the proteins by excessive cross-linking.

In the MALDI-TOF mass spectra recorded in the reflector mode, a signal at $\mathrm{m} / \mathrm{z} 2963.5$ corresponds to the monoisotopic $[\mathrm{M}+\mathrm{H}]^{+}$peak of M13, whereas a signal at $\mathrm{m} / \mathrm{z} 3597.3$ was assigned to intramolecularly cross- linked M13. The mass difference of $\sim 634 \mathrm{u}$ corresponds well with the mass increase caused by sulfo-SBED when both ${ }^{\circ}$ reactive ${ }^{\circ}$ sites $^{\circ}$ have ${ }^{\circ}$ reacted $^{\circ}{ }^{\circ}$ with $^{\circ}$ the ${ }^{\circ}$ peptide ${ }^{\circ}$ (Table 1). ${ }^{\circ}$ From $^{\circ}$ the ${ }^{\circ}$ MALDI-TOF ${ }^{\circ}$ mass $^{\circ}$ spectra $^{\circ}$ recorded $^{\circ}$ in linear mode it is evident that a significant amount of cross-linking product between CaM and M13 is created after UV irradiation times of at least $120 \mathrm{~min}$, with the cross-linked CaM/M13 (1:1) complex containing between two to five cross-linkers. Moreover, CaM was found to be intramolecularly modified with one to five molecules ${ }^{\circ}{ }^{\circ}{ }^{\circ}$ sulfo-SBED ${ }^{\circ}$ (Figure $\left.{ }^{\circ} 2 b\right)$.

\section{Identification of Reaction Products}

After the cross-linking reaction, reaction mixtures were subjected to enzymatic in-solution digestion with trypsin. These mixtures were rather complex as they contained peptides derived from CaM and M13 in addition to inter- and intramolecular cross-linking products as well ${ }^{\circ}$ as $^{\circ}$ peptides $^{\circ}$ modified $^{\circ}$ by $^{\circ}$ sulfo-SBED ${ }^{\circ}\left(\right.$ Table $\left.^{\circ} 1\right) .{ }^{\circ}$ To enrich cross-linker containing species, peptide mixtures were subjected to affinity purification using monomeric avidin ${ }^{\circ}$ beads. ${ }^{\circ}$ In $^{\circ}$ Figure $^{\circ} 3,{ }^{\circ}$ MALDI-TOF ${ }^{\circ}$ mass $^{\circ}$ spectra from various stages of the avidin separation are presented, at the example of the reaction mixture of CaM and M13, which had been treated with 100-fold excess of sulfo-SBED and irradiated for $8 \mathrm{~h}$. The spectrum in 


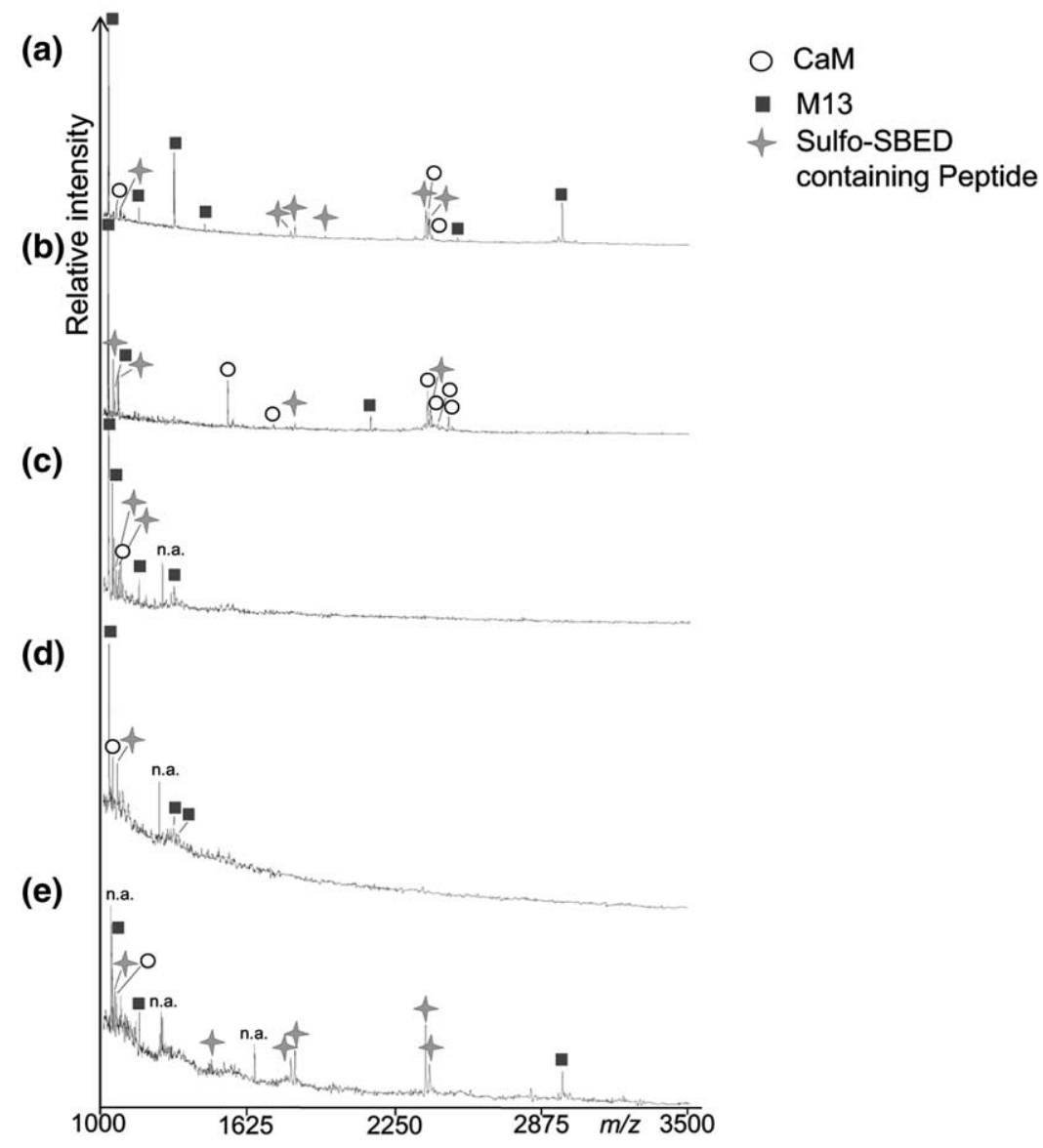

Figure 3. MALDI-TOF mass spectra of different fractions from avidin purification of CaM/M13 reaction mixture (100-fold excess sulfo-SBED, UV irradiation time $8 \mathrm{~h}$ ). (a) Total cross-linking reaction mixture before avidin purification; (b) supernatant; (c) first phosphate fraction; (d) first fraction eluted with $15 \%$ methanol in $50 \mathrm{mM}$ ammonium bicarbonate; (e) first fraction eluted with $50 \%$ aqueous acetonitrile in $0.4 \%$ formic acid. Signals of M13 (filled square) and CaM (open circle) peptides as well as cross-linker containing peptide species (filled diamond) are labeled; n.a.: signal not assigned.

Figure $^{\circ} 3 \mathrm{a}^{\circ}$ presents $^{\circ}$ the $^{\circ}$ total $^{\circ}$ reaction ${ }^{\circ}$ mixture ${ }^{\circ}$ before avidin separation, showing a number of peaks that were identified as tryptic peptides originating from both CaM and M13. Moreover, weak signals corresponding to sulfo-SBED modified peptides were observed in this spectrum. The MALDI-TOF mass spectrum $^{\circ}\left(\text { Figure }^{\circ} 3 \mathrm{~b}\right)^{\circ}$ of $^{\circ}$ the $^{\circ}$ supernatant ${ }^{\circ}$ exhibits $^{\circ}$ similar signals, however, some signals of M13 peptides are missing, which might have been bound nonspecifically to the avidin beads. Three washes of the avidin beads with phosphate buffer yielded spectra as shown in Figure $3 c^{\text {fofor }}$ the first 9 hosphate buffer 9 raction in which mainly unmodified peptide are detected. A subsequent wash with $15 \%$ methanol in $50 \mathrm{mM}$ ammonium bicarbonate showed elution of a few CaM and M13 peptides (Figure ${ }^{\circ} 3 \mathrm{~d}$ ), ${ }^{\circ}$ but $^{\circ}$ also $^{\circ}$ some $^{\circ}$ sulfo-SBED ${ }^{\circ}$ modified $^{\circ}$ peptides were beginning to elute during the second washing step with methanol (data not shown). Finally, Figure $3 e^{\circ}$ shows ${ }^{\circ}$ the ${ }^{\circ} \mathrm{MALDI}-\mathrm{TOF}^{\circ} \mathrm{mass}^{\circ}$ spectrum ${ }^{\circ}$ of the solution (50\% aqueous acetonitrile in $0.4 \%$ formic acid) that was used to elute biotinylated species from the beads. This spectrum predominantly contains sulfo-
SBED derivatized CaM and M13 peptides, which had only been observed as weak signals in the original reaction mixture before avidin separation.

The fractions from the avidin separation were also analyzed by nano-HPLC/nano-ESI-FTICR mass spectrometry, as the FTICR technique offers unprecedented mass resolution and mass accuracy, thus allowing for a more confident assignment of cross-linking products. Figure ${ }^{\circ}{ }^{\circ}$ shows ${ }^{\circ}$ the ${ }^{\circ}$ deconvoluted ${ }^{\circ}$ ESI-FTICR ${ }^{\circ}$ mass ${ }^{\circ}$ spectrum of the avidin-purified peptide fraction (peptides eluted with $50 \%$ aqueous acetonitrile in $0.4 \%$ formic acid) of the above mentioned CaM/M13 reaction mixture. The cross-linker containing species are summarized $^{\circ}$ in $^{\circ}$ Table $^{\circ} 2{ }^{\circ}{ }^{\circ}$ confirming ${ }^{\circ}$ that ${ }^{\circ}$ more ${ }^{\circ}$ cross-linkermodified species are detected when UV irradiation times are increased from $60 \mathrm{~min}$ to $8 \mathrm{~h}$. Strikingly, most of the assigned signals in the ESI-FTICR mass spectrum shown ${ }^{\circ}$ in $^{\circ}$ Figure $^{\circ} 4^{\circ}$ originate $^{\circ}$ from ${ }^{\circ}$ peptides ${ }^{\circ}$ that ${ }^{\circ}$ have been modified by sulfo-SBED. Merely one signal at $\mathrm{m} / \mathrm{z}$ 2963.726 corresponds to intact, unmodified M13 peptide, which apparently had been retained on the avidin beads despite extensive washing steps described above. 


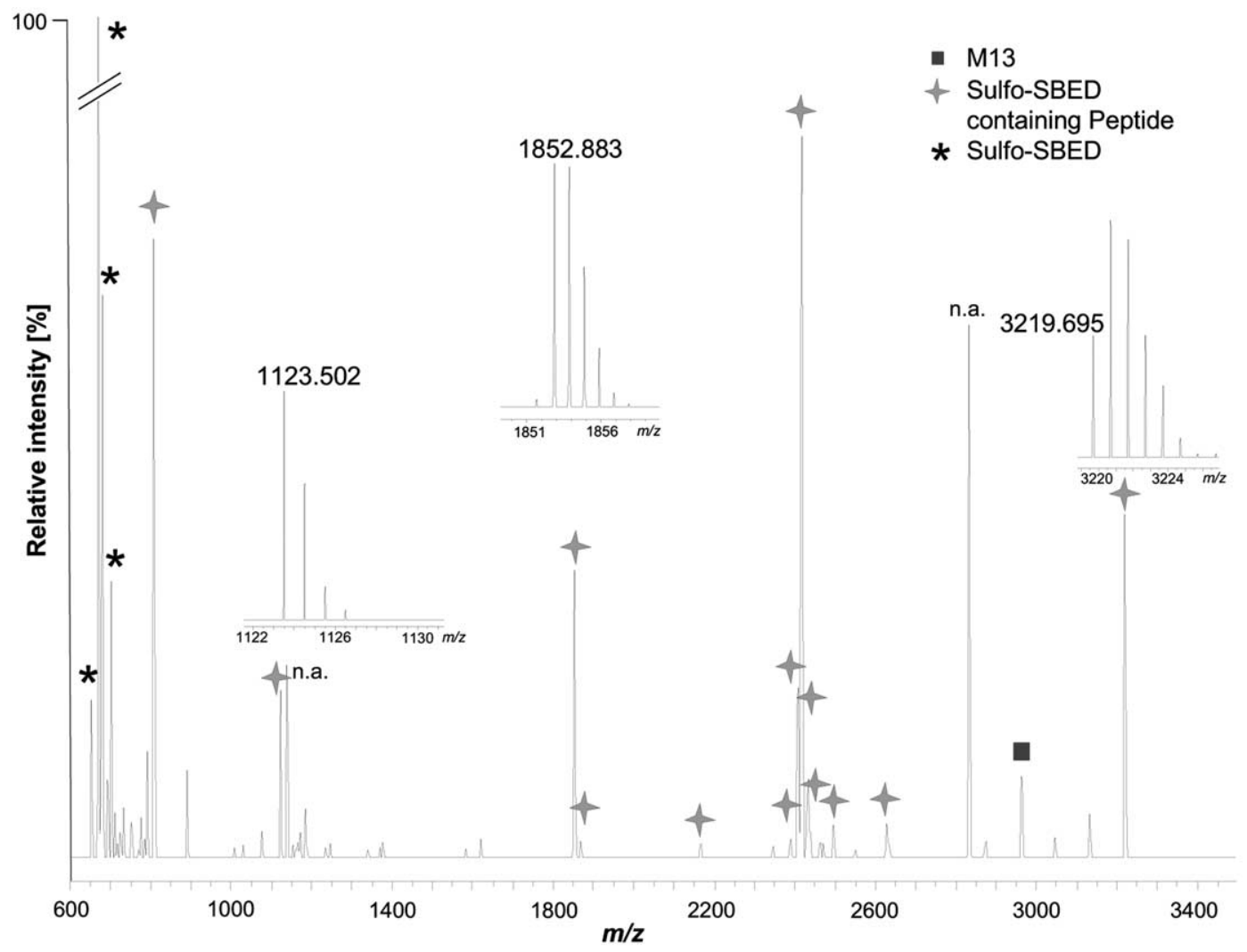

Figure 4. Deconvoluted ESI-FTICR mass spectrum of an avidin purified peptide mixture (first acetonitrile fraction, 100-fold excess of sulfo-SBED over protein/peptide concentration, irradiation time $8 \mathrm{~h}$ ). Signals of cross-linker containing peptide species (filled diamond), reacted sulfo-SBED (filled star), and the M13 peptide (filled square) are labeled; n.a.: signal not assigned.

The high mass accuracy of the ICR technique presents an invaluable requirement for a correct assignment of cross-linker containing species. Based on MALDI-TOFMS data alone, the signal at $\mathrm{m} / \mathrm{z} 2963.726$ (Figure $\left.^{\circ} 4\right)^{\circ}$ might $^{\circ}$ also $^{\circ}$ have $^{\circ}$ been $^{\circ}$ assigned $^{\circ}$ to $^{\circ} \mathrm{a}^{\circ}$ cross- $^{-}$ linking product comprised of amino acids 4-19 of M13 and amino acids 75-77 of CaM. However, the calculated monoisotopic mass $\left([\mathrm{M}+\mathrm{H}]^{+}\right)$of the respective crosslinking product is $2963.539 \mathrm{u}$, which deviates $63 \mathrm{ppm}$ from the experimentally obtained mass. Another example for the necessity to rely on high mass accuracy data and on MS/MS data for a correct assignment of crosslinker-containing species presents the signal at $\mathrm{m} / \mathrm{z}$ 2417.099, which could possibly correspond to an oxidization ${ }^{\circ}$ product ${ }^{\circ}$ of $^{\circ}$ amino ${ }^{\circ}$ acids ${ }^{\circ} 107-126^{\circ}$ of $^{\circ} \mathrm{CaM}^{\circ}$ (Table 1).$^{\circ}$ However, ${ }^{\circ}$ the $e^{\circ}$ oxidation ${ }^{\circ}$ product $^{\circ}$ of ${ }^{\circ}$ this ${ }^{\circ}$ peptide would have calculated monoisotopic mass $\left([\mathrm{M}+\mathrm{H}]^{+}\right)$ of $2417.174 \mathrm{u}$, which deviates by $37 \mathrm{ppm}$ from the experimentally obtained value. Conclusively, this peptide can be confidently assigned to a sulfo-SBED modified peptide (amino acids 91-106), in which Lys-94 has reacted with the cross-linker. Alternatively, the signal at $\mathrm{m} / \mathrm{z} 2417.099$ could originate from a cross-linking product comprised of amino acids 1-2 of M13 and amino acids 75-86 of CaM. The unambiguous identification of the signal at $m / z 2417.099$ was achieved by tandem mass spectrometry showing b- and y-type ions of the CaM sequence ${ }^{\circ} 91-106^{\circ}\left(\right.$ VFDKDGNGYISAAELR $^{\circ}\left(\right.$ Figure $\left.^{\circ} 5\right)$. The lysine residue at position 94 was identified as the amino acid that had reacted with SBED B- $\mathrm{N}_{3}$ based on the mass shifts of the respective b- and y-type ions caused by reaction with the cross-linker $(\Delta \mathrm{m} 662.2 \mathrm{u})$. Unmodified y-type ions are observed from $\mathrm{y}_{3}$ to $\mathrm{y}_{12}$, whereas $y_{13}, y_{14}$, and $y_{15}$ ions with the mass shifts caused by SBED B- $\mathrm{N}_{3}$ are visible as doubly charged signals; b-type ions $b_{4}$ to $b_{12}$ with the mass shift caused by SBED B- $\mathrm{N}_{3}$ are observed as singly charged signals (Figure 5 ). This ${ }^{\circ}$ proves ${ }^{\circ}$ that 1 lysine $94^{\circ}$ is $^{\circ}$ modified ${ }^{\circ} y^{\circ}$ the cross-linker. Lys-94 had already been found to be highly reactive in our previous studies on the CaM/ M13 ${ }^{\circ}$ complex $[10]$.

A signal at $m / z 1084.490$, appearing exclusively in the reaction mixture (100-fold excess of sulfo-SBED over protein/peptide concentration) that was irradiated for $120 \mathrm{~min}$, was assigned to amino acids 17-19 of M13, which were modified by reaction of Lys-18 with the NHS ester group of sulfo-SBED (calc. [M +

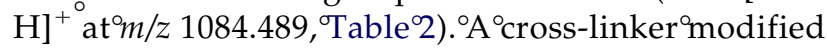
peptide consisting of amino acids 75-77 of CaM possesses a calculated monoisotopic mass $\left([\mathrm{M}+\mathrm{H}]^{+}\right)$ of $1084.456 \mathrm{u}$, which deviates by $31 \mathrm{ppm}$ from the 
Table 2. Summary of assigned signals in the deconvoluted ESI-FTICR mass spectra of avidin purified peptide mixtures (first acetonitrile fractions) using 100-fold excess of sulfo-SBED over protein/peptide concentration with irradiation times of 60 min, 120 $\mathrm{min}$, and $8 \mathrm{~h}$. The unambiguously assigned sulfo-SBED containing species are printed in shaded areas. The signal at $\mathrm{m} / z 2417.099$ is marked with an asterisk, indicating that it was identified based on MS/MS experiments (Figure 5). Ox1, ox2: Oxidation products.

\begin{tabular}{|c|c|c|c|c|c|c|}
\hline$[\mathrm{M}+\mathrm{H}]^{+}$calc. & {$[\mathrm{M}+\mathrm{H}]^{+}$exp. } & M13 Sequence & CaM Sequence & Type & Deviation [ppm] & $\begin{array}{l}\text { Irradiation } \\
\text { Time }\end{array}$ \\
\hline \multirow{3}{*}{809.326} & 809.326 & $1-1$ & - & Peptide + linker (SBED B- $\mathrm{N}_{3}$ ) & 0 & $8 \mathrm{hrs}$ \\
\hline & 809.323 & & & & 3 & $120 \mathrm{~min}$ \\
\hline & 809.324 & & & & 2 & $60 \mathrm{~min}$ \\
\hline 965.427 & 965.427 & $1-2$ & - & Peptide + linker (SBED B-N ${ }_{3}$ ) & 0 & $120 \mathrm{~min}$ \\
\hline 1084.489 & 1084.490 & $17-19$ & - & Peptide + linker (SBED B-N ${ }_{3}$ ) & -1 & $120 \mathrm{~min}$ \\
\hline \multirow[t]{3}{*}{1123.500} & 1123.502 & $4-6$ & - & Peptide + linker (SBED B-N ${ }_{3}$ ) & -2 & $8 \mathrm{hrs}$ \\
\hline & 1123.502 & & & & -2 & $120 \mathrm{~min}$ \\
\hline & 1123.496 & & & & 3 & $60 \mathrm{~min}$ \\
\hline 1842.881 & 1842.886 & $6-16$ & - & Peptide + linker (SBED A) & -3 & $120 \mathrm{~min}$ \\
\hline 1852.877 & 1852.883 & $6-16$ & - & Peptide + linker (SBED B-N ${ }_{3}$ ) & -3 & $8 \mathrm{hrs}$ \\
\hline 1868.872 & 1868.880 & $6-16$ & - & $\begin{array}{l}\text { Peptide }+ \text { linker (SBED B-N } \\
\text { ox1) }\end{array}$ & -4 & $8 \mathrm{hrs}$ \\
\hline 2167.051 & 2167.059 & $4-16$ & - & Peptide + linker (SBED B-N ${ }_{3}$ ) & -4 & $8 \mathrm{hrs}$ \\
\hline 2389.073 & 2389.085 & - & $\begin{array}{c}116-126 \\
75-77\end{array}$ & X-Link (SBED) & -5 & $8 \mathrm{hrs}$ \\
\hline \multirow[t]{2}{*}{2407.088} & 2407.097 & - & $91-106$ & $\begin{array}{l}\text { Peptide }+ \text { linker (SBED A or } \\
\text { SBED B- } \mathrm{NH}_{2} \text { ox1) }\end{array}$ & -4 & $8 \mathrm{hrs}$ \\
\hline & 2407.100 & & & & -5 & $120 \mathrm{~min}$ \\
\hline \multirow[t]{2}{*}{2417.084} & 2417.099 & - & $91-106^{*}$ & Peptide + linker (SBED B-N ${ }_{3}$ ) & -7 & $8 \mathrm{hrs}$ \\
\hline & 2417.098 & & & & -6 & $120 \min$ \\
\hline \multirow[t]{2}{*}{2417.108} & 2417.099 & $1-2$ & $75-86$ & X-Link (SBED) & 4 & $8 \mathrm{hrs}$ \\
\hline & 2417.098 & & & & 4 & $120 \mathrm{~min}$ \\
\hline 2433.078 & 2433.090 & - & $91-106$ & $\begin{array}{l}\text { Peptide }+ \text { Linker (SBED B- } \mathrm{N}_{3} \\
\text { ox1) }\end{array}$ & -5 & $8 \mathrm{hrs}$ \\
\hline 2433.103 & 2433.090 & $1-2$ & $75-86$ & X-Link (SBED, ox1) & 5 & $8 \mathrm{hrs}$ \\
\hline 2439.078 & 2439.081 & - & $91-106$ & Peptide + linker (SBED A ox2) & -1 & $8 \mathrm{hrs}$ \\
\hline 2497.108 & 2497.129 & - & $14-30$ & $\begin{array}{l}\text { Peptide }+ \text { linker (SBED A or } \\
\text { SBED B- } \mathrm{NH}_{2} \text { ox } 1 \text { ) }\end{array}$ & -8 & $8 \mathrm{hrs}$ \\
\hline 2497.144 & 2497.129 & $1-5$ & $75-77$ & X-Link + Linker (SBED A ox1) & 6 & $8 \mathrm{hrs}$ \\
\hline \multirow[t]{2}{*}{2523.419} & 2523.421 & $4-26$ & - & Peptide & -1 & $120 \mathrm{~min}$ \\
\hline & 2523.404 & & & & 6 & $60 \mathrm{~min}$ \\
\hline 2635.224 & 2635.210 & $17-19$ & $1-13$ & X-Link (SBED ox1) & 5 & $8 \mathrm{hrs}$ \\
\hline 2635.234 & 2635.210 & $1-6$ & $75-77$ & X-Link + Linker (SBED B- $\mathrm{N}_{3}$ ox 1 ) & 9 & $8 \mathrm{hrs}$ \\
\hline \multirow[t]{2}{*}{2635.191} & 2635.210 & - & $75-77$ & X-Link (SBED ox2) & -7 & $8 \mathrm{hrs}$ \\
\hline & & & $1-13$ & & & \\
\hline \multirow[t]{3}{*}{2963.717} & 2963.726 & $1-26$ & - & Peptide & -3 & $8 \mathrm{hrs}$ \\
\hline & 2963.713 & & & & 1 & $120 \min$ \\
\hline & 2963.701 & & & & 5 & $60 \mathrm{~min}$ \\
\hline \multirow[t]{2}{*}{3219.664} & 3219.695 & 3-19 & $87-90$ & X-Link (SBED) & -10 & $8 \mathrm{hrs}$ \\
\hline & 3219.700 & & & & -11 & $120 \mathrm{~min}$ \\
\hline
\end{tabular}

measured mass and is therefore excluded as possible reaction product.

One intense $^{\circ}$ signal $^{\circ}$ at $^{\circ} \mathrm{m} / \mathrm{z} 2832.518^{\circ}$ (Figure 4$)^{\circ}{ }^{\circ}$ was ${ }^{\circ}$ not identified. A possible cross-linking product between amino acids 3-16 of M13 and amino acids 87-90 of CaM possesses a calculated monoisotopic mass $\left([\mathrm{M}+\mathrm{H}]^{+}\right)$ of $2832.401 \mathrm{u}$. However, as the calculated mass differs from the experimentally obtained mass by ca. 40 ppm, we were not able to unambiguously identify the ion underlying this signal. Each of the three signals at $\mathrm{m} / \mathrm{z}$ $2433.090,2497.129$, and 2635.210 could not conclusively be assigned to a single cross-linker containing species; therefore, ${ }^{\circ}$ several ${ }^{\circ}$ possibilities ${ }^{\circ}$ are $^{\circ}$ given ${ }^{\circ}{ }^{\circ}{ }^{\circ} \mathrm{Table}^{\circ} 2$. $^{\circ} \mathrm{It}^{\circ}$ is certain, however, that the respective signals do not correspond to unmodified peptides, neither from CaM nor from M13.
One cross-linking product was identified between CaM (amino acids 87-90) and M13 (amino acids 3-19), pointing to lysine residues in positions 5,6 , or 18 of M13 that had most likely reacted with the alanine residue in position 88 of CaM. The distances between the $\mathrm{N}$ atoms of these lysine residues in M13 and the C-atom of Ala-88 in CaM are 13.6, 10.8, and $12.5 \AA$, respectively, according ${ }^{\circ}$ to ${ }^{\circ}$ the ${ }^{\circ} \mathrm{NMR}^{\circ}$ structure ${ }^{\circ}$ of $^{\circ}$ this $^{\circ}$ complex $^{\circ}[15]$. The distance between the photo-reactive and the aminoreactive $^{\circ}$ function ${ }^{\circ}$ within ${ }^{\circ}$ sulfo-SBED ${ }^{\circ}$ is ${ }^{\circ} 22.8^{\circ} \AA^{\circ}[23]^{\circ}$, and due to its inherent flexibility it seems to be able to cross-link reactive groups that are within shorter distances from each other.

It seems noteworthy that signals with high intensities at $m / z 655.242$ (calculated $m / z$ 655.240) and $m / z$ 671.236 (calculated $m / z$ 671.235) were assigned to sulfo- 


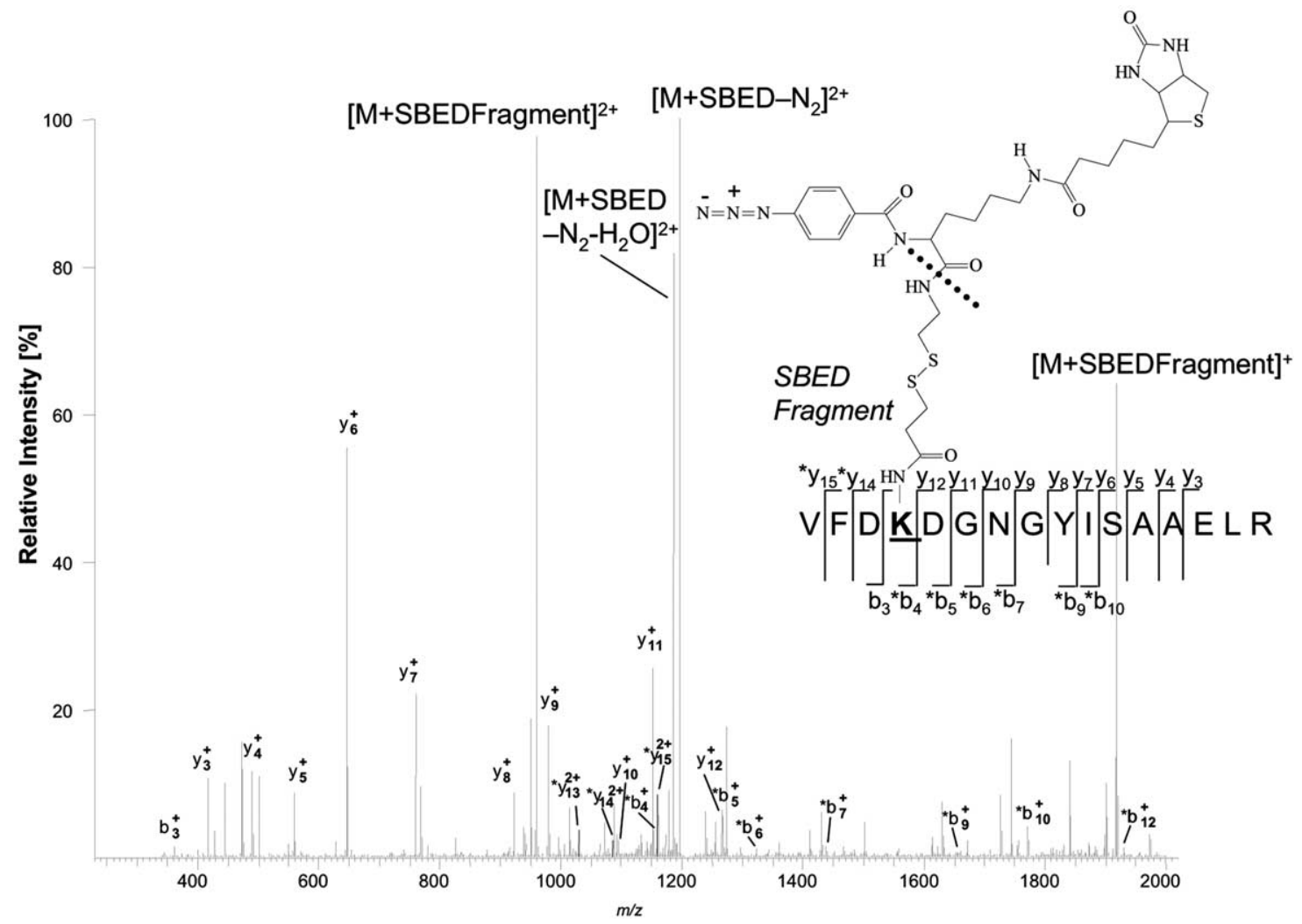

Figure 5. MS/MS of the signal at $m / z 2417.099$, which unambiguously identifies the peptide as CaM peptide comprising amino acids 91-106 with Lys-94 modified by SBED B- $\mathrm{N}_{3}\left(\mathrm{see}^{\circ}\right.$ also $^{\circ} \mathrm{Table}^{\circ} 2$ ). Fragment ions that show SBED B-N ${ }_{3}$ modification are marked with an asterisk. Fragmentation of the cross-linker occurs preferably at the amide bond (indicated as "SBED Fragment"). $\mathrm{N}_{2}$-loss from the azide group of sulfo-SBED is also observed.

SBED and its respective oxidation product in which the azide is converted to an amine group and the NHS ester moiety $^{\circ}$ is $^{\circ}$ hydrolyzed $^{\circ}\left(\right.$ Figure $\left.^{\circ} 4\right)$. $^{\circ}$ Two $^{\circ}$ other $^{\circ}$ highly abundant signals at $\mathrm{m} / \mathrm{z} 681.232$ (calculated $\mathrm{m} / \mathrm{z}$ 681.231) and $m / z 697.224$ (calculated $m / z$ 697.225) were assigned to sulfo-SBED and its oxidation product in which the NHS group is hydrolyzed, whereas the azide group stayed intact. Although we attempted to remove excess sulfo-SBED after the cross-linking reaction with CaM, the presence of highly intense sulfo-SBED species and a number of modified M13 peptides in which the NHS ester function of sulfo-SBED had reacted (designated as SBED B- $\mathrm{NH}_{2}{ }^{\circ}$ and ${ }^{\circ} \mathrm{SBED}^{\circ} \mathrm{B}-\mathrm{N}_{3}{ }^{\circ}$ species, ${ }^{\circ}$ Table ${ }^{\circ}$ ), ${ }^{\circ}$ demonstrates that the procedure of removing excess crosslinker has to be improved. For future experiments, we are planning to employ size exclusion chromatography instead of filtration by Microcon filters for sulfo-SBED removal.

The results presented herein are encouraging and clearly demonstrate that our strategy to enrich crosslinker containing species by affinity purification is highly successful in identifying cross-linking products in an efficient and rapid way. For a confident assignment of cross-linker containing species, the application of high-resolution and high mass accuracy methods, such as FTICR mass spectrometry, is a valuable pre- requisite. However, with the newest Q-TOF instruments that offer mass accuracies that begin to approach these of FTICR mass spectrometers, it might be feasible to analyze cross-linking products about as well, particularly in view of the MS/MS capabilities of Q-TOF mass spectrometers.

\section{Conclusions}

In this study, we successfully enriched cross-linker containing species by affinity purification after the cross-linking reaction. In combination with FTICR mass spectrometry, this strategy might be employed for a more efficient identification of interacting amino acid sequences in protein complexes. MS/MS experiments should be conducted to identify the exact points of cross-linking, which in future studies could be achieved by employing hybrid FTICR mass spectrometers offering the possibility to select and fragment ions before the ICR cell. Moreover, we are planning to employ crosslinkers that are both isotope-labeled and biotinylated, and which most likely will greatly facilitate an unambiguous identification of cross-linking products in case large protein assemblies are investigated. 


\section{Acknowledgments}

The junior research group of AS is funded by the Saxon State Ministry of Higher Education, Research, and Culture and the Deutsche Forschungsgemeinschaft (DFG project number Si 867/ 7-1). Financial support from the Thermo Electron Corporation (Mattauch-Herzog award of the German Society for Mass Spectrometry to AS) is also gratefully acknowledged. The authors are indebted to Dr. Ad Bax for the generous gift of M13 and to Professor Neil Kelleher, Dr. Iain Mylchreest, and Mr. Paul Thomas for their assistance with MS/MS measurements using the LTQ mass spectrometer.

\section{References}

1. Engen J. R.; Smith, D. L. Investigating the higher order structure of proteins: Hydrogen exchange, proteolytic fragmentation, and mass spectrometry. In Methods in Molecular Biology Vol. CXLVI Mass Spectrometry of Proteins and Peptides; Chapman, J. R., Ed.; Human Press Inc.: Totowa, 2000, p 95.

2. Loo, J. A. Studying Noncovalent Protein Complexes by Electrospray Ionization Mass Spectrometry. Mass Spectrom. Rev. 1997, 16, 1-23.

3. Back J. W.; de Jong, L.; Muijsers, A. O., de Koster, C. G. Chemical Cross-Linking and Mass Spectrometry for Protein Structural Modeling. J. Mol. Biol. 2003, 331, 303-313.

4. Sinz, A. Chemical Cross-Linking and Mass Spectrometry for Mapping Three-Dimensional Structures of Proteins and Protein Complexes. J. Mass Spectrom. 2003, 38, 1225-1237.

5. Fenn, J. B.; Mann, M.; Meng; C. K.; Wong, S. F.; Whitehouse, C. M. Electrospray Ionization for Mass Spectrometry of Large Biomolecules. Science 1989, 46, 64-71.

6. Karas, M.; Hillenkamp, F. Laser-Desorption Ionization of Proteins with Molecular Masses Exceeding 10,000 Daltons. Anal. Chem. 1988, 60, 2299-2301.

7. Schulz, D. M.; Ihling, C.; Clore, G. M.; Sinz, A. Mapping the Topology and Determination of a Low Resolution ThreeDimensional Structure of the Calmodulin-Melittin Complex by Chemical Cross-Linking and High-Resolution FTICR Mass Spectrometry: Direct Demonstration of Multiple Binding Modes. Biochemistry 2004, 43, 4703-4715.

8. Sinz, A.; Wang, K. Mapping Protein Interfaces with a Fluorogenic Cross-Linker and Mass Spectrometry: Application to Nebulin-Calmodulin Complexes. Biochemistry 2001, 40, 79037913.
9. Trester-Zedlitz, M.; Kamada, K.; Burley, S. K.; Fenyö, D.; Chait, B. T.; Muir, T. W. A Modular Cross-Linking Approach for Exploring Protein Interactions. J. Am. Chem. Soc. 2003, 125, 2416-2425.

10. Kalkhof, S.; Ihling, C.; Mechtler, K.; Sinz, A. Chemical CrossLinking and High-Performance Fourier Transform Ion Cyclotron Resonance Mass Spectrometry for Protein Interaction Analysis: Application to a Calmodulin/Target Peptide Complex. Anal. Chem. 2005, 77, 495-503.

11. Carafoli, E. Calcium signaling: A tale for all seasons. Proc. Natl. Acad. Sci. U.S.A. 2002, 99, 1115-1122.

12. Babu, Y. S.; Sack, J. S.; Greenhough, T. J.; Bugg, C. E.; Means, A. R.; Cook, W. J. Three Dimensional Structure of Calmodulin. Nature 1985, 315, 37-40.

13. Babu, Y. S.; Bugg, C. E.; Cook, W. J. Structure of Calmodulin Refined at 2.2 A Resolution. J. Mol. Biol. 1988, 204, 191-204.

14. Barbato, G.; Ikura, M.; Kay, L. E.; Pastor, R. W.; Bax, A. Backbone Dynamics of Calmodulin Studied by ${ }^{15} \mathrm{~N}$ Relaxation Using Inverse Detected Two-Dimensional NMR Spectroscopy: The Central Helix is Flexible. Biochemistry 1992, 31, 5269-5278.

15. Herring, B. P.; Stull, J. T.; Gallagher, P. J. Domain Characterization of Rabbit Skeletal-Muscle Myosin Light Chain Kinase. J. Biol. Chem. 1990, 265, 1724-1730.

16. Ikura, M.; Clore, G. M.; Gronenborn, A. M.; Zhu, G.; Klee, C. B.; Bax A. Solution Structure of a Calmodulin-Target Peptide Complex by Multidimensional NMR. Science 1992, 256, 632-638.

17. Hurst, G. B.; Lankford, T. K.; Kennel, S. J. Mass Spectrometric Detection of Affinity Purified Crosslinked Peptides. J. Am. Soc. Mass Spectrom. 2004, 15, 832-839.

18. Shanthoshkumar, P.; Sharma, K. K.Identification of a Region in Alcohol Dehydrogenase that Binds to $\alpha$-Crystallin During Chaperone Action. Biochim. Biophys. Acta 2002, 1598, 115-121.

19. Laemmli, U. K. Cleavage of Structural Proteins During Assembly of Head of Bacteriophage-T4. Nature 1970, 227, 680685.

20. BioAPEX User's Manual; Bruker Daltonics: Billerica, MA, 1996; $\mathrm{v} 1.1$.

21. Schwieters, C. D.; Clore, G. M. The VMD-XPLOR Visualization Package for NMR Structure Refinement. J. Magn. Reson. 2001, 149, 239-244.

22. Comisarov, M. B.; Marshall, A. G. Fourier-Transform IonCyclotron Resonance Spectroscopy. Chem. Phys. Lett. 1974, 25, 282-283.

23. Applications Handbook and Catalog; Pierce Biotechnology Inc.: Rockford, IL, 2003/2004. 